\title{
PROBLEMATIKA NAFKAH MANTAN ISTERI PASCA PERCERAIAN
}

Oleh

\section{Musa Arifin}

Dosen Fakultas Syariah dan Ilmu Hukum IAIN Padangsidimpuan email : musaarifin@iain-padangsidimpuan.ac.id

\begin{abstract}
Abstrac
Marriage is a sacred thing, that is not just getting legal status, but also various consequences as a result of the engagement ('aqad) to be woven. In a legal marriage, it is mandatory for the husband to provide a living for his wife and submit accordingly. But the reality that occurs in the community, not infrequently husband and wife relations lead to divorce, which then raises new problems, namely the granting of rights in the form of livelihood. The provision of this income is related to the time limit for living, the deadline is the difference between Asghar Ali Engineer and the opinion of the majority of scholars.
\end{abstract}

Kata Kunci; Pemberian, Nafkah, Mantan, Isteri, dan Iddah

\section{A. Pendahuluan}

Sebagaimana dalam perkawinan yang memuat hak dan kewajiban antara suami dan isteri, demikian juga jika terjadi perceraian maka ada akibat hukum darinya. Hal ini untuk menjaga adanya keseimbangan dan keadilan, sebab ketika mereka pertama kali melangsungkan perkawinan sehingga ketika berpisah pun juga harus secara baik-baik. Salah satu hak istri pasca perceraian adalah pemberian nafkah.Ulama meriwayatkan dua kata dasar bagi nafkah (nafqah; النفقة); ada yang mengatakan ia berasal dari akar kata al-infaq yang berarti pengeluaran (الإخراج), ada juga yang mengatakan bahwa ia berasal dari akar kata alnufuq yang berarti hancur (الهلاك). Ibn Bakar menjelaskan bahwa nafkah yang dimaksud di sini bukanlah berasal dari akar kata al-nufuq, nafaq atau nifaq. Akan tetap ia merupakan nama bagi sesuatu yang dinafkahkan seseorang terhadap keluarganya ( ما ينفقه الإنسان على عباله ${ }^{3}$ Sedang secara syara', seperti disebutkan al-Munawiy, ${ }^{4}$ ia berarti sesuatu yang mesti dibayarkan seseorang buat kehidupan orang yang menjadi tanggungannya, seperti isterinya, budaknya dan hewan ternaknya (ما يلزم المرء صرفه لمن عليه مؤونته من زوجته أو قنه أو دابته). Materi nafkah itu sendiri biasanya dibatasi pada tiga unsur utama, yaitu makanan, pakaian dan tempat tinggal (الطعام و الكسوة و السكنى).5

Sedang menurut Zakiyah Darajat dalam bukunya “ Ilmu Fiqh” beliau mendefinisikan nafkah berarti "belanja", maksudnya adalah sesuatu yang diberikan oleh seseorang kepada isteri, kerabat dan miliknya sebagai keperluan pokok bagi mereka, keperluan pokok seperti 
makanan, pakaian dan tempat tinggal. Definisi ini mengandung pengertian bahwa nafkah adalah segala macam kebutuhan hidup manusia bagi kebutuhan pribadinya maupun kebutuhan bagi orang di luar dirinya.

Menurut hukum Islam nafkah dibagi secara global menjadi dua macam Pertama: nafkah untuk dirinya sendiri yakni kewajiban seorang manusia untuk memikul beban tanggung jawab dalam rangka memenuhi kebutuhannya sendiri, untuk kesejahteraan jasmani, dan rohaninya sendiri. Kedua: nafkah untuk orang di luar diri, tentu saja dalam hal ini adalah anak isteri orang tuanya dan berbagai macam tanggung jawab nafkah bagi orang-orang di luar diri manusia itu sendiri.Sedang pengertian nafkah dalam perceraian sebagaimana terdapat dalam tafsir as-Sabuni, bahwa nafkah itu diartikan sebagi mut'ah, yang berarti pemberian seorang suami kepada isterinya yang diceraikan, baik itu berupa uang, pakaian atau pembekalan apa saja sebagai bantuan dan penghormatan kepada isterinya itu serta menghindari dari kekejaman talak yang dijatuhkannya itu.

\section{B. Hukum Pemberian Nafkah}

Mayoritas ulama sepakat bahwa suami berkewajiban memenuhi semua kebutuhan isterinya selama masa iddah, seperti makanan, pakaian, dan tempat tinggal. Karena dalam masa ini si suami masih berpeluang untuk rujuk kepadanya. ${ }^{6}$ Tentang jumlah nafkah, jumhur ulama, selain ulama Syafi'iyyah, menetapkan bahwa jumlah nafkah itu diberikan secukupnya. Mereka tidak mengemukakan jumlah pasti dalam penentuan nafkah tersebut, tapi hanya menetapkan sesuai dengan kemampuan suami, sejalan dengan firman Allah: ${ }^{7}$

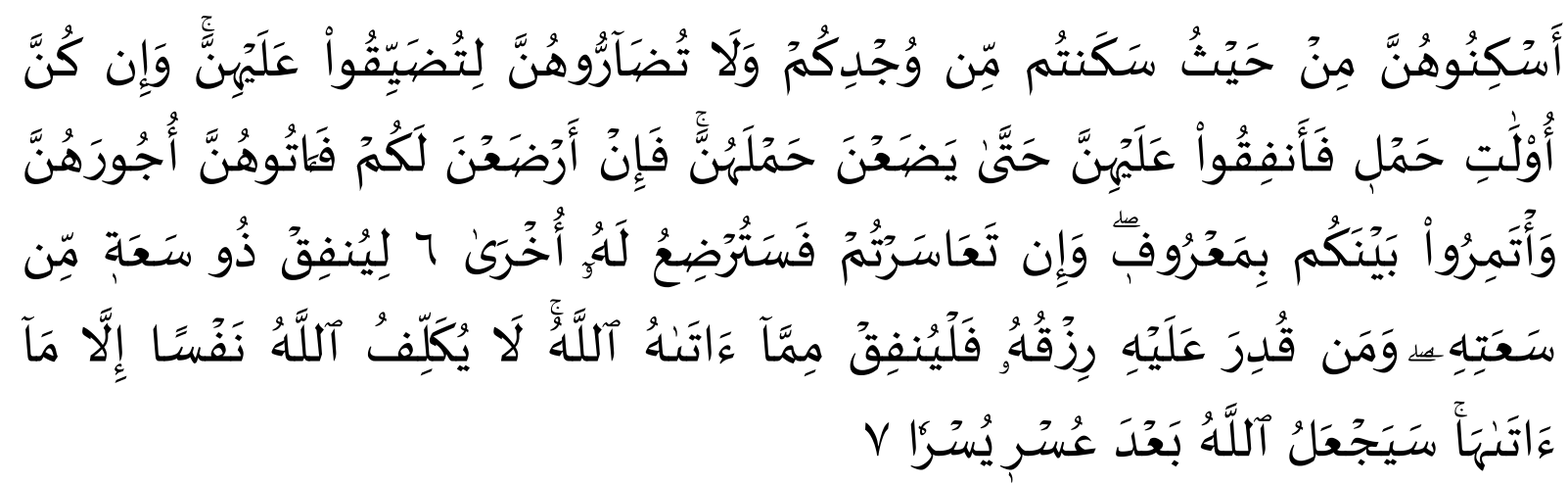

Artinya:

"Tempatkanlah mereka (para isteri) di mana kamu bertempat tinggal menurut kemampuanmu dan janganlah kamu menyusahkan mereka untuk menyempitkan (hati) mereka. dan jika mereka (isteri-isteri yang sudah ditalaq) itu sedang hamil, Maka berikanlah kepada mereka nafkahnya hingga mereka bersalin, kemudian jika mereka menyusukan (anak-anak)mu untukmu Maka berikanlah kepada mereka upahnya, dan musyawarahkanlah di antara kamu 
(segala sesuatu) dengan baik; dan jika kamu menemui kesulitan Maka perempuan lain boleh menyusukan (anak itu) untuknya".

"Hendaklah orang yang mampu memberi nafkah menurut kemampuannya. dan orang yang disempitkan rezkinya hendaklah memberi nafkah dari harta yang diberikan Allah kepadanya. Allah tidak memikulkan beban kepada seseorang melainkan sekedar apa yang Allah berikan kepadanya. Allah kelak akan memberikan kelapangan sesudah kesempitan”.

Menurut mereka, kata ma'ruf yang terdapat dalam ayat itu lebih mengacu pada ada kebiasaan setempat. Artinya, nafkah wajib yang dikeluarkan suami terhadap isterinya disesuaikan dengan kondisi dan situasi suami dan keadaan setempat.

Menurut ulama Syafi'iyyah, nafkah berupa makanan ditentukan sejalan dengan kemampuan suami. Dalam bentuk yang agak ideal, al-Ghazaliy menyebutkan, berdasarkan kesepakatan (الاتفاق) ulama, ada lima unsur nafkah yang wajib dipenuhi suami, yaitu makanan, lauk pauk, pakaian, tempat tingggal, perlengkapan kecantikan. Di samping itu, jika sebelumn ya si isteri terbiasa memiliki pelayan, maka suami juga berkewajiban menyediakan pelayan baginya, sebagai bagian dari kewajiban nafkahnya. ${ }^{8}$ Segala kebutuhan pelayan itu sendiri juga menjadi kewajiban suami untuk memenuhinya. Al-Syarbayniy melengkapi rincian nafkah yang menjadi hak isteri menjadi tujuh macam, yaitu makanan, lauk pauk, pakaian, perlengkapan kecantikan, perabotan rumah tangga, tempat tinggal dan pelayan (kalau si isteri terbiasa memiliki pelayan). ${ }^{9}$

Jumlah nafkah minimal yang harus dibayarkan suami juga tidak seragam; kalau si suami termasuk kurang mampu secara ekonomi, maka ia wajib memberi nafkah sebanyak satu mudd (675 gram gandum atau beras) untuk satu harinya. Kalau ia termasuk kelas menengah, ia wajib menafkahi satu setengah mudd (1.012,5 gram gandum atau beras) untuk satu harinya. Sedang kalau ia termasuk kategori kaya, maka ia wajib menafkahi sebanyak dua mudd (1.350 gram gandum atau beras) sehari. Variasi kewajiban itu merupkan realisasi dari firman Allah dalam surat al-Thalâq ayat 7 di atas. Penetapan jumlah kewajiban itu sendiri ditetapkan dengan melakukan analogi kepada kewajiban kafarat. Di mana antara keduanya (nafkah dan kafarat) sama-sama kewajiban yang ditetapkan syara' dan tetap menjadi tanggungan sampai ia dilunasi. Jumlah terbesar yang ditetapkan pada kafarat adalah dua mudd (untuk orang miskin), yaitu kafarat melukai ketika sedang ihram haji. Sedang jumlah paling sedikit adalah satu mudd, yaitu kafarat zhihar. Sedang untuk kelas menengah ditetapkan jumlah pertengahan antara yang terbesar dan terkecil. ${ }^{10}$

Nafkah juga diatur dalam hukum positif di Indonesia yaitu yang berlaku di Pengadilan termuat dalam Undang-undang No. 1 Tahun 1974, tentang Perkawinan pasal 41 c, yang 
berbunyi: Pengadilan dapat mewajibkan kepada mantan suami untuk memberikan biaya penghidupan dan atau menentukan sesuatu kewajiban kepada mantan isteri. Sedangkan dalam Kompilasi Hukum Islam di Indonesia, Buku I Hukum Perkawinan Bab XVII pasal 149 (a) dan pasal 158 (a dan b) yang berbunyi:

Pasal 149.

a. "Bilamana perkawinan putus karena talak, maka bekas suami wajib memberikan mut'ah yang layak kepada bekas isterinya, baik berupa uang atau benda kecuali bekas isteri tersebut qabla dukhul."

Pasal 158.

Mut'ah wajib diberikan oleh bekas suami dengan syarat:

a. Belum ditetapkan mahar bagi isteri ba'da dukhul.

b. Perceraian itu atas kehendak suami."

Dari pasal-pasal tersebut dapat ditarik kesimpulan bahwa seorang wanita yang telah dicerai masih berhak mendapatkan nafkah dari mantan suaminya tersebut sesuai dengan ketentuan-ketentuan yang terdapat pada pasal-pasal tersebut.

\section{Pemberian Nafkah Bagi Mantan Isteri}

Islam sebagai ajaran memberikan perlindungan yang maksimal kepada perempuan secara umum, secara khusus perlindungan bagi mantan isteri. Hal ini sejalan dengan apa yang terkandung dalam al-Qur'an, sehingga perempuan tidak menderita sedapat mungkin, baik secara fisik maupun secara emosional. Penderitaan secara emosional berusaha dikurangi dengan menganjurkan laki-laki agar melepaskan mantan istri mereka dengan cara yang baik. Penderitaan secara fisik bisa dikurangi dengan memberikan nafkah sebaik-baiknya.

isteri. Jalan pemberian mut'ah ini merupakan pengakuan suami atas kewajibannya bahwa ia harus membiayai isterinya yang telah diceraikannya itu, tetapi tidak mengikat untuk waktu yang lama hanya membayarnya sekaligus, kebiasaan yang demikian harus ditingkatkan menjadi pelaksanaan lebih ketat kepada kehendak QS: 241 di atas, biaya hidup bagi mantan isteri yang bersangkutan dengan syarat-syarat yang wajar, jadi jangan hanya bersifat uang penghibur saja tetapi harus bersifat uang kewajiban, hal ini suatu ketentuan yang juga akan mempersulit terjadinya perceraian, ${ }^{11}$ dapat disimpulkan bahwa pemberian nafkah (mut'ah) tidak hanya sebagai uang penghibur, tetapi sebagai uang kewajiban yang harus dibayarkan. 
Segala sesuatu dinilai benar atau salah harus dikaitkan dengan hakekat yang sesungguhnya terjadi pada masyarakat itu sendiri serta niat ketundukan terhadap hukum, demi kemaslahatan dan demi untuk menghindari sesuatu yang potensial menimbulkan madharat adalah wajib, bahkan hal demikian harus didahulukan dari upaya meraih kemanfaatannya. ${ }^{12}$

Perbedaan pendapat Asghar tersebut kalau dicermati secara seksama, terletak pada model penafsiran yang dikembangkannya, khususnya dalam menafsirkan surat al-Baqarah ayat 241 , tentang pemberian nafkah bagi mantan isteri. Dalam ayat tersebut tidak ada sesuatu yang membatasi masa kepada seseorang untuk memberikan nafkah, dan juga tidak ada suatu ketetapan yang menghalangi seorang untuk memberikan nafkah bagi mantan isteri melebihi masa 'iddah. ${ }^{13}$ Al-Qur' an sendiri tidak menyatakan baik secara implisit atau eksplisit bahwa isteri yang diceraikan harus dirawat oleh orang tuanya atau kerabatnya, sebaliknya adalah kewajiban para suami untuk merawat isteri-isteri mereka. ${ }^{14}$ Asghar berusaha melakukan kontekstualisasi terhadap pemberian nafkah bagi mantan isteri selama masa 'iddah, yang selama ini masih kukuh dipegang oleh umat muslim, dan juga Kompilasi Hukum Islam, beliau juga berusaha merekonstruksi ketentuan tersebut melalui penelusuran sosial historis, ketika ayat tersebut diturunkan kemudian menginterprestasikan sesuai dengan konteks sosial, ekonomi. Murtadha Muthahhari dalam bukunya Hak-Hak Wanita dalam Islam, memberikan suatu solusi terhadap wanita apabila terjadi suatu perceraian yang berhubungan dengan harta, ketika seorang wanita hidup bersama suaminya, maka ia harus diberikan hak untuk memiliki dan dapat menyimpan kekayaannya sendiri, sekalipun seluruh nafkahnya ditanggung oleh suaminya. ${ }^{15}$

Akan tetapi cukup disayangkan bahwa adanya kesenjangan antara ajaran idealnya dengan praktek yang terjadi. Yang diperlukan kemudian adalah menanamkan nilai-nilai alQur'an dengan skala yang jauh lebih luas bagi perempuan muslim dan istri pada khususnya, sehingga mereka menjadi sadar atas hak-hak yang diberikan al-Qur'an disatu sisi dan disisi lain berusah memberikan perlindungan kepada perempuan termasuk kepada mantan istri. Ini bukanlah sebuah pekerjaan yang mudah, namun nilai manfaat yang begitu besar pekerjaan berat ini harus terus-menerus dilakukan. ${ }^{16}$

Senada dengan premis di atas, Asghar Ali Engineer memberikan pendapat yang berbeda dengan pandangan mayoritas ulama fiqh mengenai pemberian nafkah bagi mantan isteri yang mana menurut para fuqaha bahwa pemberian nafkah bagi mantan isteri hanya sebatas pada periode 'iddah. Sementara menurut Asghar tidaklah demikian adanya. Ia 
berpendapat bahwa pemberian nafkah bagi mantan isteri adalah sampai isteri menikah lagi atau wafat. Landasan yang dijadikan pegangan Asghar dalam menanggapi masalah pemberian nafkah bagi mantan isteri adalah firman Allah: ${ }^{17}$

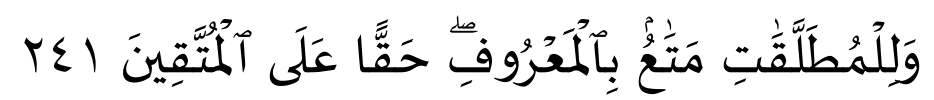

Artinya:

"kepada wanita-wanita yang diceraikan (hendaklah diberikan oleh suaminya) mut'ah menurut yang ma'ruf, sebagai suatu kewajiban bagi orang-orang yang bertakwa". \{Qs. AlBaqarah/2:241\}

Apabila dilihat secara cermat, tidak ada yang membatasi masalah pemberian nafkah bagi mantan isteri, ayat tersebut tidak menetapkan periode tertentu dan tidak juga menegaskan jumlah tertentu. Penafsiran diserahkan kepada pemahaman manusia dan tuntutan zaman yang senantiasa berubah, ${ }^{18}$ dan semuanya diserahkan kepada hakim untuk memutuskan setelah segalanya dipertimbangkan.

Asghar juga beranggapan bahwa ada dua kata kunci dalam surat al-Baqarah (2): 241, yang berkenaan dengan pemberian nafkah: Mata'a dan Ma'ruf. Al-Quran menyatakan bahwa mereka tidak hanya harus dilepaskan dengan cara yang baik ( $\left.M a^{\prime} r u f\right)$ akan tetapi perbekalan (Mata'ah) juga disediakan dengan cara yang baik pula. Berkaitan dengan permasalahan ini, belum ada ketetapan dalam hukum ini yang menghalangi seseorang memberikan nafkah melebihi masa 'iddah. Argumen bahwa umat Islam tidak bisa dipaksa membayar nafkah di luar masa 'iddah memang sangat kukuh, namun dengan adanya perubahan kondisi sosial, penerapan hukum dapat berubah juga. ${ }^{19}$ Dalam hal ini, tidak ada yang menghalangi seseorang memberikan nafkah melebihi masa 'iddah. Dengan adanya perubahan kondisi sosial, maka penerapan hukum dapat berubah juga. ${ }^{20}$ Al-Qur'an sendiri tidak menyatakan baik secara implisit maupun eksplisit bahwa isteri yang diceraikan harus dirawat oleh orang tuanya atau kerabatnya, sebaliknya adalah kewajiban para suami untuk merawat isteri-isteri mereka. ${ }^{21}$

Setelah suami meninggal, isteri tidak boleh dikeluarkan dari rumahnya, dia harus diperbolehkan menetap di sana paling tidak selama satu tahun. Hal ini sesuai dengan firman Allah: ${ }^{22}$ 


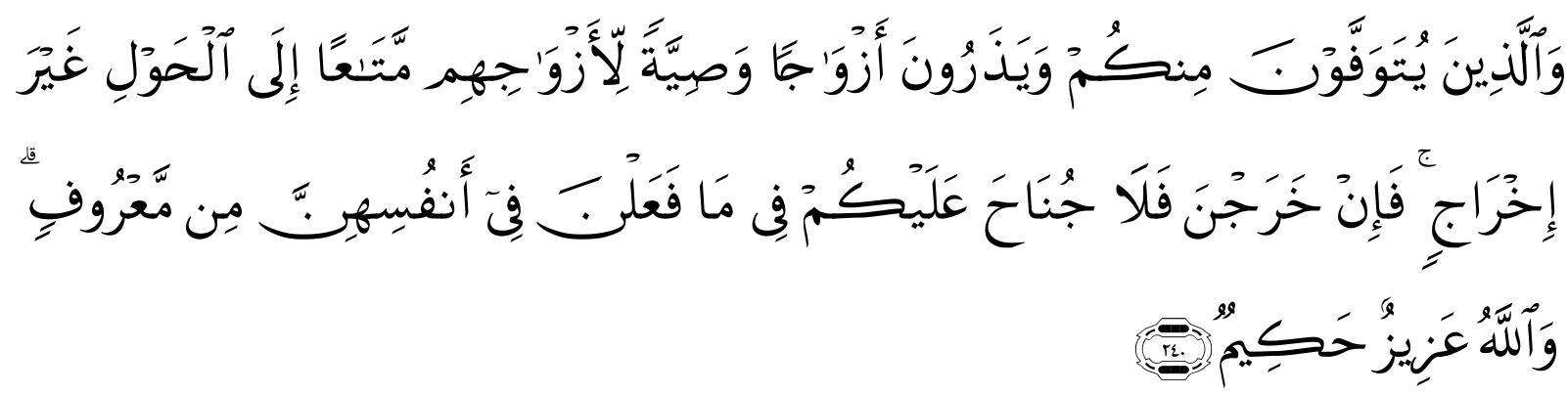

Artinya:

"Dan orang-orang yang akan meninggal dunia di antara kamu dan meninggalkan isteri, hendaklah Berwasiat untuk isteri-isterinya, (yaitu) diberi nafkah hingga setahun lamanya dan tidak disuruh pindah (dari rumahnya). akan tetapi jika mereka pindah (sendiri), Maka tidak ada dosa bagimu (wali atau waris dari yang meninggal) membiarkan mereka berbuat yang ma'ruf terhadap diri mereka. dan Allah Maha Perkasa lagi Maha Bijaksana". \{Qs. alBaqarah/2:240\}

Seseorang laki-laki dapat berbicara dengan janda cerai mati pada masa iddahnya tentang maksudnya untuk mengawininya. Hal ini menunjukkan bahwa janda tersebut dilamar pada masa 'iddahnya. Dengan demikian, sangatlah mungkin bahwa kerabat suaminya akan mendorong janda tersebut meninggalkan rumah suaminya setelah 'iddahnya habis dan mencari suami yang baru. Inilah sebab al-Quran mendesak seorang suami untuk membuat wasiat khusus sebelum meninggal dunia untuk mempertahankan isterinya di dalam rumahnya paling tidak selama satu tahun dan untuk nafkah hidupnya dan segala keuntungan lainnya (sebagai tambahan atas hak warisnya yang biasa bagi seorang isteri dari harta suaminya, seperdelapan). Dengan demikian, jika ayat ini dibaca dalam prespektif sosial yang berlaku pada saat itu, maka akan terlihat bahwa perlindugan khusus diambil untuk melindungi hakhak perempuan, (al-Baqarah (2):240).

Asghar lebih lanjut juga mengutip pendapat 'Allamah Yusuf Ali, bahwa perempuan yang dicerai berhak atas nafkah yang layak dan pemberian tersebut diwajibkan bagi suami yang menceraikannya. Sebagian ulama masa awal Islam juga berpendapat bahwa mata'ah tidak mengisyaratkan waktu tertentu. Asghar mengutip pendapatnya Hasan al-Basri, seorang tabi'in yang juga ulama besar, berpendapat bahwa" tidak ada pembatasan waktu mengenai pemberian nafkah, ini harus diberikan menurut kemampuan seseorang, demikian juga dalam Lisan al-'Arab, leksikon Arab klasik dan diakui secara luas, mengatakan," Ia (mata'ah) tidak mempunyai batas waktu, karena Allah tidak menetapkan batas waktu pemberian nafkah. Di antaranya menyuruh memberikan nafkah. ${ }^{23}$

Asghar juga mengutip pendapat seorang ulama pakistan Prof. Rafiullah Syihab, mengatakan dalam artikelnya yang dipublikasikan oleh Pakistan Times bahwa menurut 


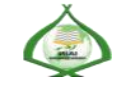

prinsip yang ditetapkan fuqaha Hanafi, “jika seorang suami tidak memberikan nafkah kepada isterinya dengan benar, isteri bisa mendapatkan pemberian nafkah yang besarnya ditetapkan pengadilan, pemberian tersebut tidak hanya diberikan sewaktu menjadi isterinya akan tetapi juga setelah ia diceraikan". ${ }^{24}$

Hal senada juga diungkapkan Imam Ibn Rujaim, “dia berpandangan bahwa argumen yang mengatakan berhentinya kewajiban pemberian nafkah selayaknya oleh suaminya dapat mengetuk pintu pengadilan dan mendapatkan nafkah yang besarnya ditetapkan pengadilan tersebut. Suami harus membayar dan memberikan nafkah yang sudah ditetapkan itu kepada isterinya secara teratur. Jika menolak melakukannya, dia akan dihukum kurungan, jika memungkinkan bagi suami untuk menyelamatkan diri dengan menceraikan isterinya, dia tentu akan melakukan yang demikian. Tetapi hukum Islam tidak membolehkannya berlaku demikian, dia tetap harus memberikan nafkah tersebut setelah menceraikannya. ${ }^{25}$ Berkaitan dengan kriteria-kriteria wanita yang berhak untuk mendapatkan nafkah dari mantan suaminya, Asghar belum menyinggung lebih lanjut, hanya saja beliau memberikan suatu pertimbangan kepada seorang hakim ketika memutuskan suatu kasus perceraian dan untuk bahan pertimbangannya seperti: 1. Apakah perceraian sesuai dengan syara', seperti bagaimankah tingkahlaku seorang wanita itu sebelum diceraikan, apakah dia taat kepada suaminya; 2. Bagaimanakah status ekonominya,dalam hal ini status ekonomi seorang wanita yang telah diceraikan, apakah dia kaya atau miskin; 3. Apakah mempunyai anak-anak dalam tanggungannya; 4. Bagaimanakah status ekonomi suaminya, untuk mengukur kemampuan seorang suami, apakah dia mampu untuk memberikan nafkah kepada mantan isterinya. ${ }^{26}$

Berkaitan dengan kriteria-kriteria bagi mantan isteri yang berhak mendapatkan nafkah dari mantan suaminya, Kompilasi Hukum Islam dalam pasal 149 memberikan gambaran, bahwasannya nafkah, maskan dan kiswah kepada mantan isteri itu hanya selama dalam 'iddah, sedangkan mantan isteri yang telah di jatuhi talak ba'in atau nusyuz dan dalam keadaan tidak hamil, tidak mendapatkan nafkah. Dari Kompilasi Hukum Islam tersebut dapat ditarik kesimpulan, bahwasannya wanita yang berhak mendapatkan nafkah dari mantan suaminya hanya wanita yang masih dalam masa 'iddah dan wanita itu sedang hamil (karena selama masa 'iddah itu untuk menggetahui apakah wanita itu hamil atau tidak), ${ }^{27}$ dan tidak pada posisi ditalak ba'in dan bukan karena wanita itu nusyuz, sedangkan berkaitan dengan talak ba'in itu sendiri masih banyak perbedaan pendapat dari kalangan ulama mazhab, seperti pendapat mazhab Hanafi yang berpendapat bahwa isteri yang dalam masa 'iddah talak ba'in tetap mendapatkan nafkah (makanan, pakaian dan rumah), Syafi'i dan Maliki berpendapat 
bahwa isteri tersebut hanya berhak atas tempat tinggal saja. ${ }^{28}$ Begitu juga dalam Hukum Islam bahwasannya kriteria bagi mantan isteri yang berhak mendapatkan nafkah dari mantan suaminya, juga hanya selama isteri menjalankan masa 'iddah, karena selama masa 'iddah hubungan perkawinan suami isteri masih tetap berlangsung, karena talak raj'i tidak menghapuskan akad nikah, tidak menghilangkan hak-hak suami atas isterinya, begitu juga hak-hak isteri terhadap suaminya. ${ }^{29}$ Sedang wanita-wanita yang tidak berhak mendapatkan nafkah dari mantan suaminnya adalah seperti: wanita yang melakukan khulu', wanita yang suaminya meninggal dunia, wanita yang menunggu masa 'iddahnya karena fasakh, ${ }^{30}$ dan setelah perceraian seorang mantan isteri itu hanya mendapatkan nafkah hanya selam masa 'iddah, tentunya hal ini sangat berbeda dengan pendapat Asghar.

Tujuan pemberian nafkah sendiri dimaksudkan untuk memberikan bantuan dan penghormatan kepada isteri serta menghindarkan dari kekejaman talak yang dijatuhkan oleh suaminya. ${ }^{31}$ Dapat dipahami juga bahwa tujuan pemberian nafkah dalam rangkaian menghindarkan kemungkinan kemadharatan setelah terjadinya perceraian, dan diharapkan dengan adanya pemberian nafkah bagi mantan isteri maka akan dapat menimbulkan kemaslahatan bagi mantan isteri tersebut jika tidak mampu mencari nafkah sendiri, dan juga mendatangkan kemudahan kepada mantan isteri tersebut. Terkadang seorang isteri yang ditalak itu miskin dan tidak ada seorang pun yang menanggungnya, maka dari itu suami yang menceraikan itu wajib untuk memberikan nafkah selama masa 'iddah serta persiapannya untuk kawin dengan suami lain. ${ }^{3210}$

Memang al-Qur'an telah mengisyaratkan perlindugan bagi mantan isteri yang diceraikan, sehingga mereka tidak menderita sedapat mungkin secara fisik maupun secara emosial. Penderitan emosial berusaha dikurangi dengan menganjurkan laki-laki agar melepaskan mereka dengan cara yang baik.

Akan tetapi disayangkan adanya kesenjagan antara ajaran idealnya dengan praktek yang terjadi. Yang diperlukan adalah menanamkan nilai-nilai al-Qur'an dalam sekala yang jauh lebih luas bagi perempuan muslim, sehingga mereka menjadi sadar, atas hak-hak yang akan dicapainya. ${ }^{33}$

Pemberian semacam uang hiburan kepada mantan isteri, apabila terjadi perceraian suami hanya memberikan sejumlah uang untuk sekali lalu saja kepada mantan isterinya tersebut, ini disebut sebagai uang hiburan karena perceraian itu terjadi tidak atas kesalahan isteri. Jalan pemberian $m u t^{\prime}$ ah ini merupakan pengakuan suami atas kewajibannya bahwa ia harus membiayai isterinya yang telah diceraikannya itu, tetapi tidak mengikat untuk waktu 
yang lama hanya membayarnya sekaligus, kebiasaan yang demikian harus ditingkatkan menjadi pelaksanaan lebih ketat kepada kehendak QS: 241 di atas, biaya hidup bagi mantan isteri yang bersangkutan dengan syarat-syarat yang wajar, jadi jangan hanya bersifat uang penghibur saja tetapi harus bersifat uang kewajiban, hal ini suatu ketentuan yang juga akan mempersulit terjadinya perceraian, ${ }^{34}$ dapat disimpulkan bahwa pemberian nafkah (mut'ah) tidak hanya sebagai uang penghibur, tetapi sebagai uang kewajiban yang harus dibayarkan.

Segala sesuatu dinilai benar atau salah harus dikaitkan dengan hakekat yang sesungguhnya terjadi pada masyarakat itu sendiri serta niat ketundukan terhadap hukum, demi kemaslahatan dan demi untuk menghindari sesuatu yang potensial menimbulkan madharat adalah wajib, bahkan hal demikian harus didahulukan dari upaya meraih kemanfaatannya. ${ }^{35}$

Perbedaan pendapat Asghar tersebut kalau dicermati secara seksama, terletak pada model penafsiran yang dikembangkannya, khususnya dalam menafsirkan surat al-Baqarah ayat 241 , tentang pemberian nafkah bagi mantan isteri. Dalam ayat tersebut tidak ada sesuatu yang membatasi masa kepada seseorang untuk memberikan nafkah, dan juga tidak ada suatu ketetapan yang menghalangi seorang untuk memberikan nafkah bagi mantan isteri melebihi masa 'iddah. ${ }^{36}$ Al-Qur'an sendiri tidak menyatakan baik secara implisit atau eksplisit bahwa isteri yang diceraikan harus dirawat oleh orang tuanya atau kerabatnya, sebaliknya adalah kewajiban para suami untuk merawat isteri-isteri mereka. ${ }^{37}$ Asghar berusaha melakukan kontekstualisasi terhadap pemberian nafkah bagi mantan isteri selama masa 'iddah, yang selama ini masih kukuh dipegang oleh umat muslim, dan juga Kompilasi Hukum Islam, beliau juga berusaha merekonstruksi ketentuan tersebut melalui penelusuran sosial historis, ketika ayat tersebut diturunkan kemudian menginterprestasikan sesuai dengan konteks sosial, ekonomi. Murtadha Muthahhari dalam bukunya Hak-Hak Wanita dalam Islam, memberikan suatu solusi terhadap wanita apabila terjadi suatu perceraian yang berhubungan dengan harta, ketika seorang wanita hidup bersama suaminya, maka ia harus diberikan hak untuk memiliki dan dapat menyimpan kekayaannya sendiri, sekalipun seluruh nafkahnya ditanggung oleh suaminya. ${ }^{38}$

Islam sesungguhnya membawa ajaran yang diyakini dapat meninggikan derajat dan martabat wanita, sayangnya ajaran-ajaran yang luhur itu sering ditafsirkan secara dangkal, sehingga tidak jarang ditemukan penafsiran yang beragam yang justru merendahkan wanita. ${ }^{39}$ Apa yang dilakukan Asghar dalam menginterprestasikan suatu ayat yang bias gender, ia lebih mengedepankan substansi dari pada legal-formalnya. Inilah yang membuat 


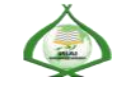

Volume 4 Nomor 2 Edisi Juli-Desember 2018

Asghar termasuk kelompok pemikir Islam liberal. ${ }^{40}$ Teori hermeneutik yang mereka gunakan berangkat dari suatu keyakinan bahwa al-Quran adalah membawa wacana keadilan yang berarti mempunyai visi kesetaraan gender.

Tidaklah berlebihan untuk melindungi hak-hak para isteri walaupun terhadap isteri yang telah diceraikan dalam pasal 17 Undang-undang No.14 tahun 1970 tentang pokokpokok kekuasaan kehakiman, menentukan bahwa segala keputusan pengadilan harus memuat alasan-alasan hakim dan dasar-dasar memutuskan perkara, dalam bagian pertimbangan dari putusan adalah alasan-alasan hakim sebagai penanggung jawab pada masyarakat, mengapa ia sampai mengambil keputusan demikian sehingga mempunyai nilai obyektif, ${ }^{41}$ berdasarkan Undang-undang no. 1 tahun 1974 pasal 41 c, pengadilan dalam kasus-kasus perceraian tertentu dapat menentukan ujud dari mata', berupa sejumlah uang yang dapat menjadi biaya hidup bagi mantan isteri sehabis masa 'iddahnya untuk waktu tertentu.

Allah telah menganjurkan untuk dapat memberikan nafkah kepada orang lain, dalam hal ini tentunya dapat diterapkan pada suami terhadap isteri yang diceraikannya, seperti telah tertuang dalam surat at-Talaq ayat 6, dari ayat tersebut dapat diambil kesimpulan bahwa suami yang menceraikan isteri wajib memberikan pesangon (nafkah) baik nafkah 'iddah bila isteri terdapat ketentuan-ketentuan untuk mendapatkan nafkah maupun mut'ah sesuai dengan kemampuannya, Perlu dipahami, bahwa pelaksanaan nafkah dalam perceraian masih perlu dikaitkan dengan sebab-sebab dan kondisi pribadi yang bersangkutan yang itu nanti sangat mempengaruhi pelaksanaan nafkah itu sendiri.

Dasar filosofis yang dikemukakan Asghar adalah bahwa semua manusia sama merdeka dan makhluk berakal yang memberi kecenderungan kepada persamaan dan keadilan, oleh karena itu secara natural, akan selalu melawan segala bentuk penindasan, diskriminasi dan segala bentuk ketidakadilan dalam segala hal dan jauh dari rasa keadilan, apabila mantan isteri yang telah diceraikan harus kembali kepada orang tuanya atau kepada kerabatnya.

Bahwa setiap wanita yang diceraikan oleh suaminya berhak atas nafkah bil ma'ruf (atas ukuran sepatutnya) Qs al-Baqarah: 241, meliputi semua wanita yang diceraikan oleh suaminya baik sudah dicampuri maupun belum dicampurinya baik wanita yang ber'iddah maupun wanita yang tidak ber'iddah, berhak mendapatkan nafkah sepatutnya, dan berakhirnya nafkah, apabila wanita itu telah mendapatkan nafkah dari pihak lain, seperti jika ia telah bersuami lagi atau jika ia mempunyai perusahaan sendiri ataupun mantan suami tidak mampu lagi mengurus pihak luar karena telah payah kehidupannya, dan jika ada pertikaian tentang sanggup atau tidak sanggupnya atau tentang patut atau tidak patutnya 
(tentang ma'ruf itu sendiri) maka hakim berhak menetapkannya (berhak memberikan keputusannya). ${ }^{42}$

\section{Penutup}

Dinamika sosial baru yang terus didukung berbagai kalangan diharapkan dapat melakukan terobosan pembaharuan hukum sehingga melahirkan pembentukan peundangundangan yang konstruktif bagi pemenuhan hak-hak perempuan. Tawaran Pemikiran yang disampaikan Asghar Ali Angineer patut dipertimbangkan dalam konteks yuridis sehingga perlindungan terhadap mantan istri secara khusus bisa lebih maksimal.

\section{DAFTAR PUSTAKA}

Abdul Aziz Dahlan (ed.), Ensiklopedi Hukum Islam, cet.1, Jakarta: PT. Ichtiar Baru Van Hoeve.

Ala`al-Din Muhammad bin Aliy al-Husniy (disebut: Ibn Aliy al-Husniy), Durr al-Mukhtar fi Syarh Tanwir al-Abshar, Beirut: Dâr al-Fikr, 1386 H.

al-Ghazaliy, Muhammad bin Muhammad bin Muhammad,. al-Wasith, Kairo: Dâr al-Salam, $1417 \mathrm{H}$.

al-Jamal, Ibrahim Muhammad, Fiqh Wanita, diterj. Ansori Umar, Semarang: Asy-Syifa', 1986.

al-Jurjawi, Ali Ahmad,. Hikmah al-Tasyri' wa Falsafatuhu, diterj. Hadi mulyo, Shobahussurur.cet. 1, Semarang: asy-Syifa', 1992.

al-Jurjawi, Ali Ahmad,. Hikmah al-Tasyri' wa Falsafatuhu, diterj. Hadi mulyo, Shobahussurur.cet. 1, Semarang: asy-Syifa', 1992.

al-Nawawiy, Yahya bin Syarf bin Marw,. Tahrir Alfazh al-Tanbih, Damaskus: Dâr al-Qalam, $1408 \mathrm{H}$.

al-Qawnuniy, Qasim bin 'Abdillah bin Amir 'Ali,. Anis al-Fuqaha', Jedah: Dar al-Wafa', $1406 \mathrm{H}$.

al-Syarbayniy, Muhammad al-Khathib,. Mughniy al-Muhtaj, Beirut: Dar al-Fikr, t.th.

al-Zuhayliy, Wahbah,. al-Fiqh al-Islâmiy wa Adillatuh, Damaskus, Dar al-Fikr, 1989.

as-Sabuni, M. 'Ali, Rawa'i al-BayanTafsir al-Ahkam min al-Qur'an, Makkah: tnp,tt..

Dzhuyatin, Siti Ruhaini dkk, Rekonstruksi Metodologi Wacana Gender dalam Islam, Cet. 1

Yogyakarta: PSW IAIN Sunan Kalijaga, Mc Gill-ICIHEP dan Pustaka Pelajar, 2002.

Engineer, Asghar Ali,. Hak-Hak Perempuan Dalam Islam, Yogyakarta: LSPPA, 1994.

Hazairin, Tinjauan Mengenai U.U Perkawinan No. 1-1974, Cet. 1, Jakarta: Tintamas, 1975.

Kamal Mukhtar, Asas-asas Hukum Islam tentamg Perkawinan, cet. 3, Jakarta: Bulan Bintang, 1993.

Khallaf, Abdul Wahhab,. 'Ilmu Ushul Figh, cet.12, Mesir: Dar al-'Ilm,1978.

Khallaf, Abdul Wahhab,. 'Ilmu Ushul Figh, cet.12, Mesir: Dar al-'Ilm,1978. 
Mertokusumo, Sudikno,. Hukum Acara Perdata Indonesia, cet 1, Yogyakarta: Liberti 1993.

Mohd. Idris Ramulyo, Hukum perkawinan Islam, cet.1, Jakarta: Bumi Aksara, 1996.

Muhammad Rawwas Qai'ah, Ensiklopedi Fiqh Umar ibn Khattab, diterj. M. Abdul Mujies. Cet. 1, Jakarta: PT. Raja Grafindo Persada, 1999.

Muslim, Siti Musdah dan Anwar, Marzani,. (ed.), Keadilan dan Kesetaraan Gender Prespektif Islam, cet.1, Tim Pemberdayaan Perempuan Bidang Agama Departemen Agama RI: 2001.

Muthahhari, Murtadha,. Hak-hak Wanita dalam Islam diterj. M. Hashem. Cet.6, Jakarta: Lentera, 2001.

Muthahhari, Murtadha,. Hak-hak Wanita dalam Islam diterj. M. Hashem. Cet.6, Jakarta: Lentera, 2001.

Nuryatno, M. Agus,. Islam Teologi Pembebasan dan Kesetaraan Gender, Yogyakarta: UII Press, 2001.

Ramulyo, Mohd. Idris,. Hukum perkawinan Islam, cet.1, Jakarta: Bumi Aksara, 1996.

\section{End Note :} hlm. 288.

${ }^{1}$ Yahya bin Syarf bin Marw al-Nawawiy, Tahrir Alfazh al-Tanbih, (Damaskus: Dâr al-Qalam, 1408 H),

${ }^{2}$ Qasim bin 'Abdillah bin Amir 'Ali al-Qawnuniy, Anis al-Fuqaha', ( Jedah: Dar al-Wafa', 1406 H), h. 168.

${ }^{3}$ Ala` al-Din Muhammad bin Aliy al-Husniy (disebut: Ibn Aliy al-Husniy), Durr al-Mukhtar fi Syarh Tanwir al-Abshar, (Beirut: Dâr al-Fikr, 1386 H), Juz 2, hlm. 571.

${ }^{4}$ Al-Munawiy, hlm. 703

${ }^{5} \mathrm{Al}-\mathrm{Q} a w n u n i y$, hlm. 168

${ }^{6}$ Wahbah al-Zuhayliy, al-Fiqh al-Islâmiy wa Adillatuh, (Damaskus, Dâr al-Fikr, 1989), hlm. 658.

${ }^{7}$ Qs. Ath-thalaq 65:6-7

${ }^{8}$ Muhammad bin Muhammad bin Muhammad al-Ghazaliy, al-Wasith, (Kairo: Dâr al-Salam, 1417 H), 6 :

${ }^{9}$ Muhammad al-Khathib al-Syarbayniy, Mughniy al-Muhtaj, (Beirut: Dâr al-Fikr, t.th.), 3:426

${ }^{10}$ ibid

${ }^{11}$ Mohd. Idris Ramulyo, Hukum perkawinan Islam, cet.1, (Jakarta: Bumi Aksara, 1996), hlm. 13.

${ }^{12}$ Abdul Wahhab Khallaf, 'Ilmu Ushul Figh, cet.12 (Mesir: Dar al-'Ilm,1978), hlm 207.

${ }_{13}^{13}$ Asghar Ali Engineer, Hak-hak., hlm 201.

${ }_{15}^{14}$ M. Agus Nuryatno, Islam Teologi Pembebasan,hlm. 60.

${ }^{15}$ Murtadha Muthahhari, Hak-hak Wanita dalam Islam diterj. M. Hashem. Cet.6, (Jakarta: Lentera, 2001), hlm. 143.

${ }^{16}$ Asghar Ali Engineer, Hak-Hak Perempuan Dalam Islam, (Yogyakarta: LSPPA, 1994), hlm. 208-209.

${ }^{17}$ QS.al-Baqarah 2: 241

${ }^{18}$ Asghar Ali Engineer, Hak-hak. , hlm. 202

${ }^{19}$ Ibid, hlm. 201

${ }^{20} \mathrm{Ibid}$, hlm. 200

${ }^{21}$ M. Agus Nuryatno, Islam Teologi Pembebasan dan Kesetaraan Gender (Yogyakarta: UII Press, 2001), hlm. 60.

${ }^{22}$ QS.al-Baqarah 2: 240

${ }^{23}$ Asghar Ali Engineer, Hak-hak. , hlm. 202

${ }^{24}$ Ibid.

${ }^{25}$ Ibid., hlm 203.

${ }^{26}$ Ibid.,

${ }^{27}$ Muhammad Rawwas Qai'ah, Ensiklopedi Fiqh Umar ibn Khattab, diterj. M. Abdul Mujies. Cet. 1 (Jakarta: PT. Raja Grafindo Persada, 1999) hlm 392. 
28 Abdul Aziz Dahlan (ed.), Ensiklopedi Hukum Islam, cet.1 (Jakarta: PT. Ichtiar Baru Van Hoeve) IV:1283

${ }^{29}$ Kamal Mukhtar, Asas-asas Hukum Islam tentamg Perkawinan, cet. 3 (Jakarta: Bulan Bintang, 1993) hlm. 177.

${ }^{30}$ Ibrahim Muhammad al-Jamal, Fiqh Wanita, diterj. Ansori Umar (Semarang: Asy-Syifa',1986) hlm. 463.

${ }^{31}$ M. 'Ali as-Sabuni, Rawa'i al-BayanTafsir al-Ahkam min al-Qur'an, (Makkah: tnp,tt.), II: 610.

${ }^{32}$ Ali Ahmad al-Jurjawi, Hikmah al-Tasyri' wa Falsafatuhu, diterj. Hadi mulyo, Shobahussurur.cet. 1, (Semarang: asy-Syifa', 1992), hlm 335.

10 Ali Ahmad al-Jurjawi, Hikmah al-Tasyri'wa Falsafatuhu, diterj. Hadi mulyo, Shobahussurur.cet. 1, (Semarang: asy-Syifa', 1992), hlm 335

${ }^{33}$ Asghar Ali Engineer, Hak-hak., hlm. 208-209.

${ }^{34}$ Mohd. Idris Ramulyo, Hukum perkawinan Islam, cet.1, (Jakarta: Bumi Aksara, 1996), hlm. 13.

${ }^{35}$ Abdul Wahhab Khallaf, 'Ilmu Ushul Figh, cet.12 (Mesir: Dar al-'Ilm,1978), hlm 207.

${ }^{36}$ Asghar Ali Engineer, Hak-hak., hlm 201.

${ }^{37}$ M. Agus Nuryatno, Islam Teologi Pembebasan,hlm. 60.

${ }^{38}$ Murtadha Muthahhari, Hak-hak Wanita dalam Islam diterj. M. Hashem. Cet.6, (Jakarta: Lentera, 2001), hlm. 143.

${ }^{39}$ Siti Musdah Muslim dan Marzani Anwar, (ed.), Keadilan dan Kesetaraan Gender Prespektif Islam, cet.1, (Tim Pemberdayaan Perempuan Bidang Agama Departemen Agama RI: 2001), hlm. 73.

${ }^{40}$ Di samping Asghar, pemikir Islam liberal lainnya adalah Riffat Hasan, Fatima Mernissi, Fazlur Rahman. Hal ini dapat dilihat dalam bukunya, Budhy Munawar-Rachman, Islam Pluralis., hlm. 416. Siti Ruhaini Dzhuyatin, dkk, Rekonstruksi Metodologi Wacana Gender dalam Islam, Cet. 1 (Yogyakarta: PSW IAIN Sunan Kalijaga, Mc Gill-ICIHEP dan Pustaka Pelajar, 2002), hlm. 66-67.

${ }^{41}$ Sudikno Mertokusumo, Hukum Acara Perdata Indonesia, cet 1, (Yogyakarta: Liberti 1993), hlm. 184.

${ }^{42}$ Mohd. Idris Ramulyo, Hukum perkawinan Islam, hlm.114. Lihat juga, Hazairin, Tinjauan Mengenai U.U Perkawinan No. 1-1974, Cet. 1, (Jakarta: Tintamas, 1975), hlm. 23. 